\title{
INNOVATIVE SOLUTIONS USED IN SERVICES IN MUNICIPAL WASTE MANAGEMENT SYSTEMS
}

\section{AGNIESZKA ULFIK}

The Jerzy Kukuczka Academy of Physical Education in Katowice, POLAND

e-mail: aulfik@gmail.com

RECEIVED
ACCEPTED
JEL
CLASSIFICATION

KEYWORDS

ABSTRACT
16 August 2017

15 December 2017

$\mathrm{F} 60, \mathrm{M} 14, \mathrm{M} 20, \mathrm{O10}, \mathrm{Q} 01, \mathrm{Q} 50$

municipal waste, municipal waste management, waste management systems, innovations, RFID, GPS

The basic services used in the field of municipal waste management systems are the collection and management of waste. Under these two basic services it is possible to use a series of innovates and so that the entire system from the point of view of the resident functioned in a smooth and at the same time not generate nuisance. They are introduced, among others, mobile applications, informing residents about the date of exportation of waste by specific factions. Increasingly, residents are also able to make declarations and corrections via the Internet. From the point of view of the community is also important is the use of innovative solutions in order to verify the type of waste and place of their creation. For this purpose, GPS and RFID are used. It is also very important to use innovations in waste management facilities themselves. Such solutions allow to reduce the negative impact of waste on the environment, as well as reduce the nuisance for the inhabitants, due to the reduction of the odor.

\section{Introduction}

From 1 July 2011 in Poland, has changed legislation on municipal waste management (Ustawa..., 2011), enforced by EU requirements. Since then, the municipality has been responsible for the collection and management of waste within the developed systems. Municipalities are forced to comply with high standards of waste management, and further legislative changes. 
The main assumption of the legal changes introduced is to encourage greater innovation in services related to municipal waste management systems and to create new business opportunities conducive to sustainable development in the waste management market (Lipińska, 2016; Mesjasz-Lech, 2014).

According to Directive 2006/12/EC of The European Parliament and of The Council of 5 April 2006 on waste (Directive..., 2006), term 'waste' shall mean any substance or object in the categories set out in Annex I which the holder discards or intends or is required to discard.

In practice, this means that the decision about what is municipal waste, is taken by the residents. The amount of municipal waste generated by residents shows their level of environmental awareness and behaviors they choose. Differentiation of the amount of waste generated per capita in the EU countries is very high, which has a direct impact on the waste management.

In the case of municipal waste it is also extremely important to examine how they are developed. The concept is to collect, transport, recover and dispose of waste, and to supervise these activities and places of waste disposal.

Innovative solutions applied in waste management allow to meet strict environmental protection requirements and adapt to EU requirements.

\section{Municipal waste management systems in Poland}

Legislative changes introduced in Poland in 2011 assume that the government, which is responsible for serving the local community, should also be responsible for receiving and appropriate waste management (Ulfik, Nowak, 2014).

Very important in the functioning of the municipal waste management system is the level of awareness of the inhabitants, especially in the context of segregation of waste at their place of origin (Smolnik, 2013). This has a significant impact on the cost of operating the entire system, including economic costs of environmental protection, and the selection of logistical processes needed (Bajdor, Starostka-Patyk, Lis, 2016; Krzywda, 2012). Equally important are pro-ecological solutions in enterprises, consistent with the ideas of sustainable development and corporate social responsibility.

Local governments, apart from a whole range of responsibilities aimed at improving the quality of life of local communities (Dziadkiewicz, 2013), were additionally obliged to construct, maintain and evaluate the municipal waste management system. The composition of these systems include the Regional Systems Processing Municipal Waste, which uses Best Available Technique (BAT) to apply new available waste treatment technologies or provide mechanical and biological waste treatment (Siemiatkowski, 2012) combined with the prior separation of mixed waste from municipal waste that is suitable for recovery or recycling (Piontek, 2014; Zbroński, 2015).

\section{IT Services in the management of municipal waste}

It is practically impossible to operate in any industry without the use of specialized IT tools. In terms of IT systems relating to waste management, diversity is enormous. They should have a wide range of functionality and include such functions as: creation of analyzes, forecasts, reports, statements and creation of databases for the purposes of registration and exchanging data with other entities. Applied systems should also provide the opportunity to communicate the municipality and residents via the Internet (Stępień, Kurus, Białecka, 2015).

There are many applications available on the Polish market that have all or most of these functionalities. These include the following applications: eco-soft.pl (Eko-Soft 2018 and Ewidencja Odpadów 2018), ARISCO (GOMiG®), 
darsoft.pl (package of various programs, including Ewidencja Odpadów 2018), Ulisses (Ulisses PSZOK and Ulisses ZZO), Zeto Opole (Mewa) and many other.

In the field of waste management in Poland, municipalities are obliged to fulfill the function of information in proper waste management, but above all to promote the selective collection of waste. Lack of transparent and easily accessible information about selective collection, places and dates of waste collection, discourages residents to segregate. Retention of waste selective collection points, also affects the perception of deterioration by the inhabitants of the same system (Hanczar, Pisiewicz, 2015).

Currently, the most commonly used systems, consisting in publication on the websites of the respective schedules are often very complicated, lacking in transparency and discourage their citizens to the whole system, and thus to segregate waste. Mobile applications are a good solution in this area.

\section{Mobile application "Kiedly Wywózz"}

In Poland there is more and more widely used mobile application "Kiedy Wywóz" created by SophScope Sp. z 0.0 (http://kiedywywoz.pl).

This application is an innovative solution for the communication between the residents and municipalities in terms of waste collection. Its basic functionality consists of a transparent and convenient information on the dates of collection of waste, both for single family housing, multi-family housing and companies in municipalities that use this application (for example Bielsko-Biała, Brzeg, Częstochowa, Jaworzno, Katowice, Kołobrzeg, Kraków, Kraków, Lublin, Łódź, Opole, Poznań, Sosnowiec, Tarnowskie Góry, Ustka, Wałbrzych, Warszawa, Wrocław, Zakopane).

Residents to check where and when they will be picked up individual waste fractions, only need to find the correct address. They can get information about individual factions very quickly and conveniently. In addition, the application also allows to find the Stationary Selective Municipal Waste Collection Points (SPSZOK), along with the possibility to route the map. Residents using this application may also directly from the phone with a photo, provide information about irregularities such as non-collection of waste or generated wild dump (Hanczar, Pisiewicz, 2015; Stefko, Nowak, Ulfik, 2015).

\section{The henefiits of using modern IT tools}

The applied information systems used in municipal waste management, or is not part of the functionality or for various reasons they are not implemented. Still rare in Poland functionality consists in the possibility of electronic filing and adjustments of declaration, which would significantly facilitate communication between residents and the municipality, and thus influence in a significant way to the convenience of residents. Another innovative step could be an electronic form of communication between the property owners and municipalities, even in the field of reminder fees, information on changes in the rates or the possibility of lodging a complaint. Such solutions could significantly reduce the cost of operating systems because of the reduced cost of delivering information by mail, which currently amounts to several hundred thousand zlotys per year in individual municipalities.

For such solutions, the problem remains the appropriate user authentication and security of data sent to the municipality or the company in charge of system of waste management. A good solution would be to use an electronic signature or a trusted ePUAP profile (Electronic Platform of Public Administration Services). In the case of an electronic signature, the problem is the additional costs that the user must incur. In the case of the trusted ePUAP profile, the problem is frequent failures and the system is still underdeveloped. For stable and functional 
solutions, most likely we will have to wait a bit longer and no municipality in Poland is able to deal with such problems. The solution must take place on the side of the government administration and it is the central and not the self-governmental authorities that must provide adequate solutions.

In the context of the mobile application "Kiedy Wywóz", the benefits of using it are huge. It gives every user an easy and convenient way to reach information on the waste collection schedule. Due to the great popularity of this application among Polish municipalities, it has become a monopolist on the market. Most of the big cities use this application, although also many multi-municipal and multi-urban communes have implemented this system of informing residents about the schedule of waste collection. The only downside of using this application are the costs on the side of the municipality. First of all, using the mobile application "Kiedy Wywóz" involves a license fee. Secondly, it is necessary to properly enter the schedule data into this application. However, these costs are unnoticeable within the entire waste management system. Benefits for individual users, however, are enormous. With this application you can easily check the date of collection of individual factions, which makes it easier to segregate waste, it is easy to check when each fraction will be collected. A very important social benefit of using this application in a given municipality is a quick and very easy process of reporting wild waste dumps. Thanks to such a large facilitation, wild landfills can be cleaned faster, and at the same time, because of the great ease of reporting wild dumps, there is a greater likelihood of catching the perpetrators.

\section{Use of GPS and RFID}

Among the innovations associated with IT solutions in waste management, should be mentioned more often used GPS and RFID. The use of GPS systems can be one of form of control over the process of receiving and exporting waste by the companies that win the tenders. On the proper recorders installed in the vehicles collecting the waste, are recorded events such as loading and unloading (special sensors are installed for this purpose) as well as the route of the vehicle. The use of GPS systems with recorders, prevents cheating dishonest entrepreneurs by loading the wastes from areas not covered by the tender. Another innovative improvement of this solution is the use of radio frequency identification RFID refuse trucks and containers. If all waste containers are equipped with RFID sensors and garbage trucks in RFID terminals, then such system is very secure. In addition, it also allows for greater control of the quality of waste segregation or lack thereof by the locals due to the assignment of specific containers for places (Nowak, Grabara, Ulfik, 2015; Stefko et al., 2015).

\section{Ecoinnovations used in waste management}

Scandinavian countries, Germany and Switzerland are the leading countries in Europe with innovative solutions in the field of waste management (Grzymała, 2013). In Poland, in terms of waste management, ecoinnovation is mainly used in products and processes (Urbaniec, 2015). However, they are not as frequent and widespread as among the leaders in the industry.

In the case of innovations used in waste management companies among the most common, the following should be distinguished:

1. Thermal waste treatment - consisting in the use of technologies that mainly involve combustion or pyrolysis, leading to a reduction in the amount of waste deposited, and recovery heat or electricity from the waste (Jurczyk, Koc-Jurczyk, 2017; Lapčík, 2013; Levidow, Upham, 2017; Łapińska, 2014). 
2. Technologies to reduce odor in waste treatment plants and landfills, eg. through the use of bioreactors for composting in a closed system (den Boer, den Boer, Jager, 2005; Potdar et al., 2016; Siemiątkowski, 2012).

3. Effluent treatment technologies generated at landfills.

4. Acquiring heat or electricity from biogas produced in the process of composting or in landfills in the process of fermentation of stored waste (Kalinichenko, Havrysh, Perebyynis, 2016).

5. Production of fertilizers, both in the bio composting process and in the combustion of selected waste fractions (Łapińska, 2014; Siemiątkowski, 2012).

In the case of Poland, there is still much to be done in terms of applying innovative solutions to waste management. First of all it is necessary to build more waste incineration plants.

\section{Conclusions}

According to the Ordinance of the Minister of the Environment of 14 December 2016 on levels of recycling, preparation for reuse and recovery by other methods of certain fraction of municipal waste (Rozporządzenie..., 2016), the level of recycling of paper, metal, plastics and glass in 2020 is to reach $50 \%$. To meet these high requirements, a comprehensive approach to the problem of municipal waste is needed. It may be helpful to use innovative solutions. It is important to carry out activities that will result in more efficient segregation of waste among the population. This should include, first and foremost, efficient information on the inhabitants and control of the operation of the systems. Equally important are eco-innovation measures, which reduce the negative environmental impacts of economic processes and lead to a reduction in resource use. It is hoped that the application of innovative solutions in the management of municipal waste in Poland will become more and more common and will contribute to the improvement of the situation in this sector.

\section{References}

Bajdor, P., Starostka-Patyk, M., Lis, T. (2016). The Analysis of Waste Management in Czestochowa City for the Years 2011-2014. Transportation Research Procedia, 16 (March), 16-24.

den Boer, E., den Boer, J., Jager, J. (2005). Planowanie i optymalizacja gospodarki odpadami Planowanie i optymalizacja gospodarki odpadami. Wrocław: Oddział Dolnośląski PZiTS.

Directive 2006/12/EC of the European Parliament and of the Council of 5 April 2006 on waste, Official Journal of the European Union (2006).

Dziadkiewicz, M. (2013). Temporary Premises in the Management of Municipal Property Resources. Polish Journal of Management Studies, 7, 265-281.

Grzymała, Z. (2013). Innowacje na rynku sektora komunalnego $\mathrm{w}$ Polsce $=$ Innovations on the Municipal Market in Poland. Prace Komisji Geografii Przemysłu Polskiego Towarzystwa Geograficznego, 23, 57-67.

Hanczar, P., Pisiewicz, D. (2015). Rozwiązania ICT wspomagające zbiórkę odpadów komunalnych. Studia Ekonomiczne. Zeszyty Naukowe Uniwersytetu Ekonomicznego w Katowicach, 249, 204-216.

Jurczyk, Ł., Koc-Jurczyk, J. (2017). Thermal Conversion of Municipal Waste Into Energy: Prospects for the Sub-Carpathia. Journal of Ecological Engineering, 2 (18), 157-165.

Kalinichenko, A., Havrysh, V., Perebyynis, V. (2016). Evaluation of biogas production and usage potential. Ecological Chemistry and Engineering S, 3 (23), 387-400.

Krzywda, D. (2012). Procesy logistyczne w gospodarce stałymi odpadami. Logistyka, 2, 831-838.

Lapčík, V. (2013). Municipal-Waste-To-Energy Potential. Inżynieria Mineralna, 2 (14), 125-130.

Levidow, L., Upham, P. (2017). Socio-technical change linking expectations and representations: Innovating thermal treatment of municipal solid waste. Science and Public Policy, 2 (44), 211-224. 
Lipińska, D. (2016). Gospodarka odpadowa i wodno-ściekowa. Łódź: Wydawnictwo Uniwersytetu Łódzkiego.

Łapińska, J. (2014). Kreowanie i wdrażanie ekoinnowacji produktowych i procesowych w przemyśle utylizacyjnym. Marketing i Rynek, $8,517-522$.

Mesjasz-Lech, A. (2014). Municipal Waste Management in Context of Sustainable Urban Development. Procedia - Social and Behavioral Sciences, 151, 244-256.

Nowak, S., Grabara, J., Ulfik, A. (2015). Application of RFID and ICT in Reverse Logistic in Poland. Applied Mechanics and Materials, 718, 150-155.

Piontek, W. (ed.) (2014). Poradnik dla gmin. Kompleksowe wdrożenie ustawy o utrzymaniu porządku i czystości w gminach. Kraków: Stowarzyszenie Gmin i Powiatów Małopolski.

Potdar, A., Singh, A., Unnnikrishnan, S., Naik, N., Naik, M., Nimkar, I. (2016). Innovation in solid waste management through Clean Development Mechanism in India and other countries. Process Safety and Environmental Protection, 101, 160-169.

Rozporządzenie Ministra Środowiska z dnia 14 grudnia 2016 r. w sprawie poziomów recyklingu, przygotowania do ponownego użycia i odzysku innymi metodami niektórych frakcji odpadów komunalnych (2016).

Siemiątkowski, G. (ed.) (2012). Mechaniczno-biologiczne przetwarzanie frakcji biodegradowalnej odpadów komunalnych. Opole: Wydawnictwo Instytut Śląski Sp. z 0.0.

Smolnik, P. (2013). Istota i znaczenie gospodarki odpadami komunalnymi. Zeszyty Naukowe Politechniki Częstochowskiej Zarządzanie, 10, 69-75.

Stefko, R., Nowak, S., Ulfik, A. (2015). Selected aspects of use IT in waste management. Applied Mechanics and Materials, 795, 215-219.

Stępień, M., Kurus, K., Białecka, B. (2015). It Systems Supporting Waste Management in Communities - An Overview of Innovative Functions. Management Systems in Production Engineering, 4 (20), 210-212.

Ulfik, A., Nowak, S. (2014). Determinants of Municipal Waste Management in Sustainable Development of Regions in Poland. Polish Journal of Environmental Studies, 3 (23), 1039-1044.

Urbaniec, M. (2015). Towards Sustainable Development through Eco-innovations: Drivers and Barriers in Poland. Economics and Sociology, 4 (8), 179-190.

Ustawa z dnia 1 lipca 2011 r. o zmianie ustawy o utrzymaniu czystości i porządku w gminach oraz niektórych innych ustaw (Dz.U. 2011 nr 152 poz. 897).

Wysocki, J. (2016). Strategic approach to proecological activities of companies. European Journal of Service Management, 2 (18), 63-69.

Zbroński, D. (2015). Odzysk i unieszkodliwianie odpadów komunalnych zebranych z obszarów powstania. Archiwum Gospodarki Odpadami i Ochrony Środowiska, 4 (17), 101-114.

http://kiedywywoz.pl (15.07.2017).

Cite this article as: Ulfik, A. (2018). Innovative solutions used in services in municipal waste management systems. European Journal of Service Management, 2 (26), 301-306. DOI: 10.18276/ejsm.2018.26-37. 